\title{
Implementasi Kompetensi Manajerial Kepala Sekolah dalam Meningkatkan Kinerja Guru di SMP BPI dan SMP Pasundan 1 Kota Bandung
}

Waluya Wahid Utama ${ }^{1}$, Engkus Kuswarno ${ }^{2}$, Radjamansyah ${ }^{3}$

1,2,3Sekolah Pascasarjana, Universitas Islam Nusantara Bandung, Indonesia

E-mail:wahidutamaw@gmail.com, engkuskuswarno22@gmail.com, radjamansyah113@gmail.com

\section{Article Info \\ Article History \\ Received: 2022-02-03 \\ Revised: 2022-02-22 \\ Published: 2022-03-01}

Keywords:

Competence;

Managerial;

Teacher Performance.

\begin{abstract}
Specifically, this study aims to explore, analyze and obtain data on planning, organizing, implementing and evaluating the managerial competence of SMP principals in improving teacher performance. Supporting and inhibiting factors faced by the Principal of SMP BPI and SMP Pasundan 1 to improve teacher performance. The efforts of the head of junior high school in overcoming obstacles to improve teacher performance, the impact of managerial competence of the head of junior high school on teacher performance. The research method used is descriptive method, the research technique used is participant observation, in-depth interviews and documentation. The results of the study, namely: (1) Planning has been carried out in accordance with applicable guidelines, (2) Organizing is carried out in a balanced manner by prioritizing performance, competence and rank list, (3) Implementation of managerial competence by seeking effective learning, (4) Evaluation principals in improving teacher performance by carrying out monitoring and evaluation of every activity that has been carried out, making reports on program implementation and following up on evaluation results, (5) there are supporting and inhibiting factors for school principals, (6) Efforts made by school principals in dealing with obstacles in improve teacher performance, by revitalizing MGMP and MKKS, increasing professionalism, fostering discipline for education personnel, creating harmonious working relationships, (7) The impact of implementing managerial competence of principals in these two schools is very good teacher performance.
\end{abstract}

\begin{tabular}{l}
\hline Artikel Info \\
\hline Sejarah Artikel \\
Diterima: 2022-02-03 \\
Direvisi: 2022-02-22 \\
Dipublikasi: 2022-03-01
\end{tabular}

Kata kunci: Kompetensi; Manajerial;

Kinerja Guru.

\begin{abstract}
Abstrak
Secara spesifik penelitian ini bertujuan untuk menggali, menganalisis dan memperoleh data tentang Perencanaan, pengorganisasian, pelaksanaan dan evaluasi kompetensi manajerial Kepala SMP dalam Meningkatkan Kinerja guru. Faktor pendukung dan penghambat yang dihadapi Kepala SMP BPI dan SMP Pasundan 1 untuk meningkatkan kinerja guru. Upaya Kepala SMP dalam mengatasi hambatan untuk meningkatkan kinerja guru, dampak kompetensi manajerial kepala SMP terhadap kinerja guru. Metode penelitian yang digunakan adalah metode deskriptif, teknik penelitian yang digunakan observasi berperan serta (participan observation), wawancara mendalam (in depth interview) dan dokumentasi. Hasil penelitian, yaitu: (1) Perencanaan telah dilaksanakan sesuai dengan pedoman yang berlaku, (2) Pengorganisasian dilakukan secara berimbang dengan mengutamakan kinerja, kompetensi dan daftar urut kepangkatan, (3) Pelaksanaan kompetensi manajerial dengan mengupayakan pembelajaran yang efektif, (4) Evaluasi kepala sekolah dalam meningkatkan kinerja guru dengan melaksanakan monitoring evaluasi setiap kegiatan yang sudah dilaksanakan, membuat pelaporan pelaksanaan program dan menindak lanjuti hasil evaluasi, (5) terdapat faktor pendukung dan penghambat bagi kepala sekolah, (6) Upaya yang dilakukan kepala sekolah dalam menghadapi hambatan dalam meningkatkan kinerja guru, dengan revitalisasi MGMP dan MKKS, peningkatan profesionalisme, pembinaan disiplin tenaga kependidikan, menciptakan hubungan kerja yang harmonis, (7) Dampak implementasi kompetensi manajerial kepala sekolah di dua sekolah tersebut kinerja guru sangat baik.
\end{abstract}

\section{PENDAHULUAN}

Pendidikan merupakan salah satu pilar terpenting dalam meningkatkan kualitas sumber daya manusia, dalam konteks itu tenaga kependidikan khususnya guru memegang peranan penting dan tidak bisa diabaikan karenanya berbagai kebijakan pengembangan dan peningkatan mutu guru harus senantiasa dilakukan untuk meningkatkan kualitas kinerjanya, dalam Undang-Undang Nomor 20 tahun 2003 tentang Sistem Pendidikan Nasional bahwa Pendidikan adalah usaha sadar dan terencana untuk me- 
wujudkan suasana belajar dan proses pembelajaran agar peserta didik secara aktif mengembangkan potensi dirinya untuk memiliki kekuatan spiritual keagamaan, pengendalian diri, kepribadian, kecerdasan, akhlak mulia, serta keterampilan yang diperlukan oleh dirinya, masyarakat bangsa dan negara.

Dalam upaya menghasilkan sekolah yang berkualitas, banyak faktor yang terlibat di dalamnya, salah satu peranan yang sangat menentukan adalah kepala sekolah.Kedudukan kepala sekolah dalam penyelenggaraan pendidikan di sekolah merupakan figur sentral yang bertanggung jawab terhadap lancar tidaknya kegiatan proses pendidikan di sekolah. Kepala sekolah memiliki peranan yang sangat mempengaruhi dalam mengkoordinasikan, menggerakkan, dan menyerasikan semua sumber daya pendidikan yang tersedia di sekolah, secara umum tugas dan peran kepala sekolah 2 memiliki lima dimensi kompetensi sebagaimana termaktub pada peraturan Menteri Pendidikan Nasional Nomor 13 Tahun 2007 tentang Standar Kepala Sekolah/Madrasah, yaitu kompetensi kepribadian, manajerial, kewirausahaan, supervisi, dan kompetensi sosial. Kepemimpinan kepala sekolah merupakan salah satu faktor yang dapat mendorong sekolah untuk dapat mewujudkan visi, misi, tujuan dan sasaran sekolahnya melalui program-program yang dilaksanakan secara terencana dan bertahap, Kepala sekolah dituntut mempunyai kemampuan manajemen dan kepemimpinan yang memadai agar mampu mengambil inisiatif dan prakarsa untuk meningkatkan mutu sekolah.

Manajemen sekolah merupakan suatu kegiatan yang memiliki nilai filosofi tinggi, ia harus dapat mencapai tujuan sekolah secara efektif dan efesien, pada hakikatnya upaya tersebut dilakukan untuk meningkatkan performansi (kinerja) sekolah dalam pencapaian tujuan-tujuan pendidikan, baik tujuan nasional maupun lokal institusional. Keberhasilan pencapaian tersebut akan tampak dari beberapa faktor sebagai indikator kinerja yang berhasil dicapai oleh sekolah, Kepala sekolah dituntut untuk mampu secara maksimal melaksanakan tugas dan fungsinya dalam mengelola berbagai aspek komponen sekolah untuk mencapai tujuan sekolah yang telah dirumuskan. Agar sekolah dapat mencapai tujuannya secara efektif dan efesien, maka kepala sekolah hatus melaksanakan fungsi-fungsi manajerial seperti perencanaan, pengorganisasian, pengarahan, pemberi motivasi, pelaksanaan, pengendalian, evaluasi dan inovasi. Begitu besarnya peranan sekolah dalam proses pencapaian tujuan pendidikan, demikian halnya dengan guru. Guru akan baik kinerjanya jika kepala sekolah senantiasa membina dan membimbingnya, guru merupakan komponen 5 paling menentukan dalam sistem pendidikan secara keseluruhan, guru selalu terkait dengan komponen manapun dalam pendidikan dan merupakan komponen paling berpengaruh terhadap terciptanya proses dan hasil pendidikan yang berkualitas. Oleh karena itu upaya perbaikan apapun yang dilakukan untuk meningkatkan kualitas pendidikan tidak akan memberikan sumbangan yang signifikan tanpa didukung oleh guruyang profesional dan berkualitas.

Demikian halnya dengan kondisi pendidikan di Kota Bandung, tentu memiliki strategi, model, dan nilai-nilai implementasi pengelolaan lembaga pendidikan oleh kepala sekolah yang khas, meskipun sama-sama dalam ruang lingkup manajerial, oleh karena itu hal ini semakin memperkuat rencana penelitian ini untuk meneliti lebih lanjut bagaimana implementasi kompetensi manajerial kepala sekolah di beberapa sekolah yang ada di Kota Bandung. Sekolah yang akan dijadikan lokasi penelitian adalah Sekolah Menengah Pertama (selanjutnya disingkat SMP BPI) Kota Bandung, dan Sekolah Menengah Pertama Pasundan 1 Kota Bandung, kedua sekolah ini selama ini merupakan sekolah yang memiliki reputasi baik, yang berada di Kota Bandung, meskipun sekolah swasta. Sekolah dengan reputasi baik tentu bukan tanpa alasan, pasti karena sekolah tersebut memiliki indikatorindikator tertentu, SMP BPI Kota Bandung diantaranya sekolah ini mampu mengukir banyak prestasi akademik dan nonakademik yang baik, tidak saja dalam lingkum lokal, namun sudah mencapai lingkup nasional, tidak saja bagi peserta didik, prestasi juga diraih oleh guru SMP BPI dan SMP Pasundan 1 Kota Bandung. Keberhasilan dua sekolah di atas, tidak lepas dari peran kepala sekolah yang mampu mengelola sekolah dengan baik, dimana mereka mampu memaksimalkan setiap sumber daya yang ada di sekolah, menjadi energi untuk terus meningkatkan dan membudayakan mutu di sekolah masing-masing.

\section{METODE PENELITIAN}

Metode penelitian ini adalah metode deskriptif kualitatif dimana metode ini bertujuan untuk memperoleh gambaran yang jelas tentang kejadian tertentu yang dan pada akhirnya tujuan 
penelitian dapat dicapai yaitu mengenai gejalagajala yang terjadi saat sekarang. Penelitian ini menggunakan jenis penelitian lapangan (field research) yang bersifat kualitatif, metode penelitian kualitatif sangat cocok untuk di gunakan dalam penelitian ini, karena relevan dengan tujuan dari penelitian, adapun tujuan umunya yaitu untuk mengungkap data-data penelitian secara natural dan mendalam di lokasi penelitian, dalam penelitian kualitatif, pengumpulan data dilakukan pada natural setting (kondisi yang almiah), sumber data primer, dan teknik pengumpulan data lebih banyak pada observasi berperan serta (participan observation), wawancara mendalam (in depth interview) dan dokumentasi. Penelitian ini dilaksanakan di SMP BPI dan SMP Pasundan 1 Kota Bandung, adapun pertimbangan memilih sekolah tersebut adalah kedua sekolah ini merupakan sekolah yang berstandar nasional dan memiliki reputasi baik dengan segudang prestasi, di wilayah yang berbeda di Kota Bandung.

\section{HASIL DAN PEMBAHASAN}

\section{Deskripsi Temuan dan Hasil Penelitian di SMP BPI Bandung}

a) Implementasi kompetensi manajerial Kepala SMP BPI Kota Bandung dalam penyusunan perencanaan untuk meningkatkan kinerja guru. Perencanaan merupakan suatu tahapan awal dari sebuah organisasi untuk melaksanakan operasionalnya, perencanaan yang baik akan berpengaruh terhadap pelaksanaan pekerjaan yang lebih terarah dan teratur sehingga hasil yang diperolehnya akan lebih optimal. Terkait dengan implementasi perencanaan program kinerja guru di SMP BPI Bandung memiliki tiga bentuk perencanaan yaitu program jangka panjang, jangka menengah dan progam jangka pendek, ketiga program tersebut saling terkait dan berhubungan satu-sama lain.

b) Implementasi kompetensi manajerial Kepala SMP BPI Kota Bandung dalam mengorganisasikan sumber daya untuk meningkatkan kinerja guru. Organizing merupakan tahapan manajemen yang terkait dengan penempatan personil dalam suatu organisasi, dalam organisasi pendidikan tentunya terkait dengan bagaimana kepala sekolah melakukan pembagian tugas mengajar guru di sekolah. Dalam penempatan personil pada jabatan tertentu di SMP BPI Bandung, beberapa pertimbangan yang dilakukan kepala sekolah adalah:

1) Penilaian terkait dengan kompetensi guru terhadap bidang tugas yang akan diberikan.

2) Kinerja guru dan kompetensi guru.

3) Daftar urut kepangkatan (DUK).

Langkah yang ditempuh kepala sekolah dalam menempatkan personil dalam suatu jabatan adalah:

1) Pemetaan kebutuhan.

2) Berdiskusi dengan wakil dan staf yang terkait dengan bidang kegiatan yang akan dilakukan.

3) Pemetaan kompetensi dan kinerja guru.

4) Pengajuan calon.

5) Wawancara dengan calon perihal kesiapan kerja dan pembuatan komitmen.

6) Penunjukkan dan sosialisasi.

Dalam pembagian tugas mengajar, sebagian besar tugas mengajar yang diberikan pada guru di SMP BPI Bandung telah sesuai dengan kualifikasi pendidikan guru, semua guru mendapat jumlah jam mengajar lebih dari jam minimal. Kondisi ini disebabkan karena jumlah guru yang ada belum mencukupi kebutuhan secara penuh, untuk itu kepala sekolah telah melakukan be-berapa usaha pemenuhan kebutuhan tenaga guru seperti permohonan kepada Dinas Pendidikan Kota Bandung melalui usulan DSO atau menerima tenaga honorer, berhasilnya peng-organisasian terjadi jika ada kesinergian seluruh personil yang ada, oleh karena itu pola interaksi yang diterapkan di sekolah turut mempengaruhi apakah pelaksanaan program yang direncan-kan akan dapat berjalan dengan baik dan menghasilkan sesuatu yang baik pula sesuai dengan harapan.

c) Implementasi kompetensi manajerial Kepala SMP BPI Kota Bandung dalam mengaktualisasikan sumber daya untuk meningkatkan kinerja guru, pelaksanaan peningkatan kinerja guru di SMP BPI Bandung pada hakikatnya merupakan implementasi dari misi sekolah. Misi tersebut tentunya suatu cara mencapai tujuan sekolah, untuk itu keseluruhan warga sekolah harus bersinergi untuk tetap bekerja dengan sasaran pada 
pencapaian visi dan tujuan sekolah. Dari hasil wawancara, observasi dan studi dokumentasi yang ada, proses pelaksanaan yang dilakukan oleh kepala sekolah untuk mewujudkan visi sekolah mengupayakan pembelajaran yang efektif bagi siswa-siswanya. Strategi kepala sekolah dalam mewujudkan budaya dan iklim kerja yang kondusif antara lain dengan mengupayakan penataan lingkungan fisik sekolah sehingga terciptakan suasana yang nyaman dan indah, membangun pojokpojok literasi dekat ruang kelas, membangun integritas dengan disertai pemantauan yang bersifat kekeluargaan, dalam hubungan ini secara umum hubungan antara warga sekolah di SMP BPI Kota Bandung ini baik, guru dan tenaga kependidikan yang ada dalam hal-hal tertentu selalu berkomunikasi, dan bahkan saling memberikan solusi jika ada kesulitan yang ditemui, untuk itu struktur sekolah telah dibentuk sedemikian rupa agar iklim sekolah tetap kondusif, dengan hal-hal ini kesadaran individual menjadikan guru-guru SMP BPI Bandung telah bersinergi dan berkomitmen untuk selalu mening-katkan kualitas kinerjanya.

d) Implementasi Kompetensi Manajerial Kepala SMP BPI Kota Bandung dalam Mengevaluasi Program Untuk Meningkatkan Kinerja Guru, hasil wawancara dan obeservasi di SMP BPI kota Bandung, kepala sekolah melakukan evaluasi terhadap seluruh kegiatan di sekolah, termasuk program peningkatan kinerja guru. Evaluasi dilakukan dengan tujuan untuk mengukur keberhasilan kegiatan yang telah dilaksanakan, evaluasi dilakukan oleh kepala sekolah dan pengawas Pembina yang dibantu oleh para wakasek yaitu meninjau apakah program-program kerja yang telah direncanakan dan dilaksanakan berjalan dengan optimal atau belum, evaluasi juga sebagai alat ukur untuk melihat apakah program yang telah direncanakan sesuai dengan yang dilaksanakan. Dari hasil monitoring dan evaluasi yang dilakukan oleh kepala sekolah, kepala sekolah tidak hanya memanggil ataupun menegur akan tetapi membimbing guru yang bersangkutan untuk dapat memperbaikinya, dan juga menyampaikan hasil evaluasi dan monitoring pada rapat rutin setiap bulan, agar semua stake holder sekolah dapat mengetahui dan menjadi pelecut semangat/motivasi dalam mencapai tujuan pendidikan. Berdasarkan wawancara dan observasi, hasil monitoring selain dilaporkan juga ditindak lanjuti agar memberikan dampak nyata untuk meningkatkan profesionalisme guru, Kepala sekolah melakukan tindak lanjut tersebut berupa penguatan dan penghargaan diberikan kepada guru yang telah memenuhi standar.

e) Faktor Pendukung dan Penghambat yang Dihadapi Kepala SMP BPI Kota Bandung dalaM Mengimplementasikan Kompetensi Manajerial Untuk Meningkatkan Kinerja Guru. Berdasarkan hasil wawancara faktor pendukung dan penghambat yang dihadapi Kepala sekolah adalah sebagai berikut:

a) Faktor internal (dari individu) yang meliputi: SDM sebagian besar guru yang baik, sebagian besar guru memiliki motivasi dan budaya kerja yang bagus, usia muda dengan intelektual yang mumpuni, kesiapan dan ketersediaan materi untuk meningkatkan kinerja, rasa ingin tahu meningkatkan dan menambah ilmu, wawasan dan pengalaman pada guru, dan adanya kepedulian sesama rekan sejawat untuk membantu dan bersama meningkatkan kinerja guru.

b) Faktor Eksternal meliputi: program sekolah tersedia untuk memfasilitasi guru meningkatkan kinerjanya, sarana prasarana yang memadai, terbuka dengan kemudahan akses, daya dukung sekolah penuh, iklim sekolah kondusif untuk mengembangkan kualitas kinerja guru, dan program sekolah yang baik.

Berdasarkan hasil wawancara, adapun hambatan yang dihadapi kepala sekolah dalam meningkatkan kinerja guru yaitu, diantaranya:

a) faktor internal meliputi: masih ada guru yang belum maksimal dalam menjalankan tupoksinya, kurangnya pemahaman moral dari guru, masih ada Guru yang belum menguasai IT, motivasi kerja yang kurang, kurangnya pengalaman dari guru-guru dan intelektualitas sebagian guru yang masih kurang.

b) Faktor eksternal meliputi sering terjadinya kelambatan pencairan dana Bantuan Operasional Sekolah (BOS), 
masih terbatasnya anggaran dari pemerintah, dam masih ada sarana prasarana yang belum terpenuhi.

f) Upaya Kepala SMP mengatasi hambatan dalam mengimplementasikan kompetensi manajerial dalam meningkatkan kinerja guru meningkatkan kinerja guru. Berdasarkan hasil wawancara, observasi dan studi dokumentasi upaya yang dilakukan oleh kepala sekolah mengatasi hambatan dalam meningkatkan kinerja guru, yaitu dengan langkah-langkah penyelesaian masalah yang pertama menemukan akar permasalahan mencari tahu kenapa kinerja guru menurun, kemudian menganalisis akar permasalahan melalui teori SWOT: apa kekurangan \& kelebihan dari kinerja guru, selanjutnya setelah diketahui kekurangan dan kebihan kinerja guru kepala sekolah merangkai alternative pemecahan masalah.

g) Dampak implementasi kompetensi manajerial Kepala SMP terhadap kinerja guru, kinerja seseorang dipengaruhi oleh pendidikan yang melatar bekanginya. Sesuai dengan standar pendidik, untuk dapat melaksanakan tugas dengan baik, maka seorang guru harus memiliki pendidikan khusus keguruan serendahrendahnya pada jenjang Strata 1 atau diploma IV, di SMP BPI guru yang sudah S2 ada lima orang, dalam kaitannya dengan kualifikasi akademik guru di SMP BPI Bandung sudah $100 \%$ sesuai dengan kualifikasi yaitu pendidikan S1 bidang keguruan. Disamping pendidikan formal, untuk meningkatkan kinerjanya, guru-guru di sekolah tersebut telah mengikuti berbagai pelatihan baik yang diselenggarakan oleh sekolah maupun oleh organisasi lain seperti diklat fungsional MGMP, IHT atau webinar-webinar secara online.

\section{Deskripsi Temuan dan Hasil Penelitian di SMP Pasundan 1 Kota Bandung}

a) Implementasi kompetensi manajerial Kepala SMP Pasundan 1 Kota Bandung dalam penyusunan perencanaan untuk meningkatkan kinerja guru, dari hasil wawancara dan studi dokumentasi yang ada, perencanaan di SMP Pasundan 1 Bandung sudah lebih terarah. Berikut adalah hasil penelitian terkait dengan perencanaan di SMP Pasundan 1 Bandung, sekolah memiliki program jangka panjang
10 tahun, program jangka menengah 4 tahun dan program jangka pendek 1 tahun, program jangka pendek ini akan menjadi landasan sekolah dalam melaksanakan kegiatan selama satu tahun yang sedang berjalan, dengan demikian program jangka pendek ini menjadi program strategis untuk mengantarkan arah tujuan sekolah.

b) Implementasi kompetensi manajerial Kepala SMP Pasundan 1 Kota Bandung dalam mengorganisasikan sumber daya untuk meningkatkan kinerja, dalam organisasi pendidikan tentunya berarti terkait dengan bagaimana kepala sekolah melakukan pembagian tugas mengajar guru di sekolah. Disamping itu dalam pengorganisasian ini pula terkait bagaimana kepala sekolah memberikan tugas tambahan yang memang harus ada dalam rangka upaya menjalankan operasional sekolah dengan baik, dalam penempatan personil pada jabatan tertentu di SMP Pasundan 1 Kota Bandung, beberapa pertimbangan yang dilakukan kepala sekolah adalah Penilaian terkait dengan kompetensi guru terhadap bidang tugas yang akan diberikan dan kinerja guru dan kompetensi guru.

c) Implementasi kompetensi manajerial SMP Pasundan 1 Kota Bandung dalam mengaktualisasikan sumber daya untuk meningkatkan kinerja guru, dari hasil wawancara, observasi dan studi dokumentasi yang ada, proses pelaksanaan yang dilakukan oleh kepala sekolah untuk mewujudkan visi sekolah mengupayakan pembelajaran yang efektif bagi siswa-siswanya. Adapun upaya yang dilakukan oleh kepala sekolah yaitu meningkatkan kualitas gurunya dengan memberikan pelatihan-pelatihan yang berkaitan dengan proses pembelajaran, misalnya sekarang pada masa pandemic guru-guru diberikan pelatihan menggunakan media berbasis teknologi, mengelola sarana dan prasarana yang mendukung proses pembelajaran dengan memfasilitasi sarana pembelajaran dengan dibuatkan suatu ruang yang khsusus digunakan untuk guru guru melaksanakan pertemuan virtual dengan siswa-siswanya atau membuat video pembelajaran, serta menciptakan budaya dan iklim kerja yang kondusif.

d) Implementasi Kompetensi Manajerial Kepala SMP Pasundan 1 Kota Bandung Dalam Mengevaluasi Program untuk 
Meningkatkan Kinerja Guru, dari hasil wawancara, observasi dan studi dokumentasi yang ada, proses evaluasi yang dilakukan oleh kepala sekolah dengan melaksanakan monitoring evaluasi setiap kegiatan yang sudah dilaksanakan, membuat pelaporan pelaksanaan program dan menindak lanjuti hasil evaluasi.hal ini sudah biasa dilakukan di SMP Pasundan 1 Kota Bandung.

e) Faktor pendukung dan penghambat yang dihadapi Kepala SMP Pasundan 1 Kota Bandung dalam meningkatkan kinerja guru, berdasarkan hasil wawancara faktor pendukung dan penghambat yang dihadapi Kepala sekolah adalah sebagai berikut:

a) Faktor internal (dari individu) meliputi: sdm sebagian besar guru sudah baik, sebagian besar guru memiliki motivasi dan budaya kerja yang bagus, banyak guru berusia muda dengan intelektual yang mumpuni, kesiapan dan ketersediaan materi untuk meningkatkan kinerja, rasa ingin tahu meningkatkan dan menambah ilmu, wawasan dan pengalaman pada guru, dan adanya kepedulian sesama rekan sejawat untuk membantu dan bersama meningkatkan kinerja guru.

b) Faktor eksternal meliputi: tersedia Program sekolah untuk memfasilitasi guru meningkatkan kinerjanya, sarana prasarana yang memadai, terbuka dengan kemudahan akses, daya dukung sekolah penuh, iklim sekolah kondusif untuk mengembangkan kualitas kinerja guru, dan program sekolah yang baik

Berdasarkan hasil wawancara, observasi dan studi dokumentasi upaya yang dilakukan oleh kepala sekolah mengatasi hambatan dalam meningkatkan kinerja guru, yaitu dengan langkah-langkah penyelesaian masalah yang pertama menemukan akar permasalahan; mencari tahu kenapa kinerja guru menurun, kemudian menganalisis akar permasalahan melalui teori SWOT (Strength, Weaknes, Opportunity, Threat) untuk menemukan faktor-faktor yang tidak siap (mengandung persoalan), dan mengupayakan langkahlangkah pemecahan persoalan apa kekurangan \& kelebihan dari kinerja guru. Selanjutnya setelah diketahui kekurangan dan kelebihan kinerja guru kepala sekolah merangkai alternatif pemecahan masalah.

\section{Pembahasan Hasil Penelitian}

Dari hasil observasi dan wawancara di SMP BPI dan SMP Pasundan 1 Kota Bandung, diperoleh data sebagian besar guru telah memiliki kompetensi pedagogis, kompetensi tersebut dapat dilihat dari kemampuan mereka menguasai dasar-dasar didaktik dan metodik sesuai dengan bidang tugasnya. Kompetensi ini ditunjang dengan kualifikasi pendidikan guru yang semuanya telah memenuhi standar yang dipersyaratkan yaitu pendidikan minimal pada jenjang S1, bahkan guru yang sudah S2 baik di SMP BPI mapun SMP Pasundan 1 Kota Bandung sudah ada. Disamping pendidikan formal untuk meningkatkan kinerjanya, guru-guru di sekolah tersebut telah mengikuti berbagai pelatihan baik yang diselenggarakan oleh sekolah maupun oleh organisasi lain seperti penataran instruktur kurikulum, penataran metode pembelajaran, penataran PTK, penataran karya tulis ilmiah, diklat fungsional MGMP, IHT atau webinar-webinar secara online. Guru- guru di SMP BPI dan SMP Pasundan 1 Kota Bandung juga telah cukup memiliki kompetensi profesional. Hal ini ditunjukkan dengan kecakapan mereka melaksanakan tugas profesinya dengan baik, bahkan beberapa orang guru memiliki prestasi baik di tingkat kota, propinsi bahkan salah satu guru ada yang meraih prestasi nasional dalam lomba olimpiade guru nasional. Konsistensi guru-guru dalam melaksanakan tugas yang diberikan.

\section{SIMPULAN DAN SARAN}

\section{A. Simpulan}

Dari penelitian di kedua sekolah tersebut bahwa didapati bahwa Implementasi Kompetensi manajerilal Kepala Sekolah dalam meningkatkan kinerja guru berdampak pada meningkatnya kinerja para pendidik dan tenaga kependidikan serta tingkat kepercayaan orang tua peserta didik terhadap sekolah. Implementasi Kompetensi manajerial kepala SMP Sawasta di Kota Bandung dalam menyusun Perencanaan untuk meningkatkan kinerja guru telah dilaksanakan sesuai dengan pedoman yang berlaku, program terdiri dari program jangka panjang untuk masa 10 tahun, program jangka menengah untuk masa 4 tahun dan program jangka pendek untuk 
masa 1 tahun. Implementasi kompetensi manajerial Kepala SMP BPI dan SMP Pasundan 1 Kota Bandung dalam mengorganisasikan sumber daya untuk meningkatkan kinerja guru, dilakukan secara berimbang. Implementasi kompetensi manajerial Kepala SMP BPI dan SMP Pasundan 1 Kota Bandung dalam mengatualisasikan sumber daya untuk meningkatkan kinerja guru pada hakikatnya merupakan implementasi dari misi sekolah, implementasi kompetensi manajerial Kepala SMP BPI dan SMP Pasundan 1 Kota Bandung dalam mengevaluasi program untuk meningkatkan kinerja guru yaitu dengan melaksanakan monitoring evaluasi setiap kegiatan yang sudah dilaksanakan, membuat pelaporan pelaksanaan program dan menindak lanjuti hasil evaluasi. Faktor pendukung dan penghambat yang dihadapi Kepala SMP BPI dan SMP Pasundan 1 Kota Bandung dalam mengimplementasikan kompetensi manajerial untuk meningkatkan kinerja guru, upaya yang dilakukan kepala sekolah dalam menghadapi hambatan dalam meningkatkan kinerja guru, dengan revitalisasi MGMP dan MKKS, peningkatan profesionalisme, pembinaan disiplin tenaga kependidikan, menciptakan hubungan kerja yang harmonis. Pemanfaatan teknologi dan informasi, Reward dan punishment, peningkatan kualitas sarana dan prasarana, optimalisasi anggaran.

\section{B. Saran}

Berdasarkan hasil penelitian dan pembahasan pada bab sebelumnya, maka rekomendasi yang dapat peneliti berikan adalah sebagai berikut:

1. Kepada Kepala SMP Swasta di Kota Bandung untuk memperhatikan aspek keberhasilan pengelolaan dan peningkatan kinerja guru selain ditentukan oleh kompetensi manajerial dan kepiawaian kepala sekolah dalam meningkatkan kinerja guru juga dipengaruhi oleh komitmen guru dan keterlibatan partisipasi dari semua civitas pendidikan sekolah untuk turut merencanakan, mengembangkan dan mengevaluasi peningkatan kinerja guru.

2. Kinerja guru dalam pembelajaran menjadi bagian terpenting dalam mendukung terciptanya proses pendidikan secara efektif terutama dalam membangun sikap disiplin dan mutu hasil belajar siswa, untuk itu guru dituntut untuk selalu mengem- bangkan kompetensi dan meningkatkan kinerjanya sehingga menjadi guru yang profesional

3. Komite sekolah sebagai mitra kerja sekolah yang berfungsi dalam peningkatan mutu pelayanan pendidikan diharapkan dapat memberikan dukungan dan kontribusi yang nyata terhadap sekolah dengan meningkatkan peran masyarakat dalam penyelenggaraan sekolah. Sehingga, timbul rasa saling memiliki dan bertanggung jawab dalam kemajuan sekolah. Sinergisme antara komite sekolah dan kepala sekolah sangat diperlukan demi terwujudnya sekolah bermutu.

4. Para peneliti lain Agar dilakukan penelitian lebih lanjut yang mampu mengungkapkan lebih dalam tentang kompetensi manajerial kepala sekolah dalam meningkatkan kinerja guru ditinjau dari berbagai bidang yang lain.

\section{DAFTAR RUJUKAN}

Ahmadi, Abdul Wahid (2016) Kompetensi Manajerial Kepala Sekolah dalam Peningkatan Profesionalisme Guru di Sekolah Menengah Kejuruan (SMK) Pancasila 8 Slogohimo Wonogiri. Tesis, mahasiswa Program Pascasarjana Institut Agama Islam Negeri Surakarta

Al-Qur'anul Karim, Terjemahan \&tajwid: Penerbit Cordoba

Aqib. Z. (2002). Profesionalisme Guru Dalam Pembelajaran. Surabaya: Cendikia

Arifin, D 2014, Manajemen Organisasi Personil dan Kepemimpinana

Arikunto, S. (2001). Dasar-Dasar Evaluasi Pendidikan. Jakarta: Bumi Aksara

Ary, Donal.(2002). An Invtation to Research in Social Education. Baverly Hills: Sage publication

Barlian. Ujang. Cepi. 2016. Manajemen Strategik Konsep dan Implementasi. Bandung: Khalifa Insan Cedekia Press

Burhanuddin. (1994). Analisis Administrasi, Manajemen dan Kepemimpinan Pendidikan. Jakarta: Penerbit Bumi Aksara.

Carudin (2012) Pengaruh Kepemimpinan Kepala Sekolah Dan Iklim Kerja Sekolah Terhadap 
Kinerja Guru ( Studi Deskriptif Analitik Pada Guru SMKNegeri Se- Kabupaten Indramayu) Jurnal penelitian Pendidikan Edisi khusus, No 2 Agustus ,Universitas Pendidikan Indonesia

Castetter, B William (1996) The Personal Function in Education administration. Newyork: Mac Millan Publishing co.inc

Dahlan, Hermanu Iriawan, dan Hamdan (2017), Pengaruh Kompetensi Manajerial Kepala Sekolah terhadap Kompetensi Sosial Guru di SMA Negeri 11 Makasar. Jurnal Ilmiah Ilmu Administrasi Publik

Danim, S dan Suparno. 2009. Manajemen dan Kepemimpinan Transformasional Kekepalasekolahan. Jakarta: Rineka Rosdakarya Offset

Danim, S. (2002). Inovasi Pendidikan dalam Upaya Peningkatan Profesionalisme Tenaga Kependidikan. Bandung: PT Pustaka Setia

Dedeh Sofia Hasanah (2014) Pengaruh Pendidikan Latihan (Diklat) Kepemimpinan Guru Dan Iklim Kerja Terhadap Kinerja Guru Sekolah Dasar Se Kecamatan Babakancikao Kabupaten Purwakarta, Jurnal penelitian Pendidikan Volume 10 no 2, Universitas Pendidikan Indonesia

Departemen Pendidikan Nasional. (2007). Sertifikasi Guru dalam Jabatan (Materi Sosialisasi sertifikasi guru)

Depdikbud RI. (1994). Pedoman Pembinaan Profesional Pendidik Sekolah Dasar. Jakarta: Direktorat Jenderal Pendidikan Dasar dan Menengah

Direktorat Jenderal Peraturan PerundangUndangan Kementerian Hukum Dan Hak Asasi Manusia Republik Indonesia 2018, "Peratuan Menteri Pendidikan dan Kebudayaan Nomor 6 Tahun 2018 tentang Penugasan Guru Sebagai Kepala Sekolah

Edition. United States Of America, tanpa penerbit

Efendy, Onong Uchjana. (1993). Human Relation dan Public Relation. Bandung: Mandar Maju

Engkay Karweti (2014) Pengaruh Kemampuan Manajerial Kepala Sekolah Dan Faktor Yang Mempengaruhi Motivasi Kerja Terhadap Kinerja Guru SLB Di Kabupaten Subang.
Jurnal penelitian Pendidikan Volume 10 No 2 Oktober 2014. Universitas Pendidikan Indonesia

Hendarman dan Rohanim. 2018. Kepala Sekolah sebagai Manajer teori dan Praktik. Bandung: PT Remaja Rosdakarya

Hendarman. 2017. Revolusi Kinerja Kepala Sekolah. Jakarta: Penerbit Indeks

Ismuha, Khairudin, dan Djailani AR (2016), Kompetensi Manajerial Kepala Sekolah dalam Meningkatkan Kinerja Guru pada SD Negeri LamklatKecamatan Darussalam Kabupaten Aceh Besar. Jurnal. Administrasi Pendidikan, Pascasarjana Universitas Syiah Kuala

Jannah, Maidatul. (2004). Manajemen Kinerja Guru Dalam Upaya Meningkatkan Profesionalisme Guru Studi Kasus di MTsN 1 Malang. Tesis, tidak diterbitkan. Malang Program Pascasarjana UIN Malang

Khoirul Camalia. (2005). Manajemen pengembangan kompetensi pendidik (studi kasus di SMA unggulan Zainul Hasan Probolinggo). Tesis tidak diterbitkan. Malang: PPs UIN Malang

Kusnan. (2007). Kemampuan Manajerial Kepala Madrasah dan Implikasinya Terhadap Kinerja Guru. Jakarta: Jurnal IQRA' Volume 3 Januari 2007

Lamatenggo. (2001). Kinerja Guru: Korelasi antara Persepsi Guru terhadap Perilaku Kepemimpinan Kepala Sekolah, Motivasi Kerja dan Kinerja Guru SD di Gorontalo. Tesis. Jakarta: Universitas Negeri Jakarta

Lazaruth, S. (1994). Kepala Sekolah dan Tanggung Jawabnya. Yogyakarta: Penerbit Kanisius

Maleong, L. (2013). Metodologi Penelitian Kualitatif. Edisi Revisi Bandung: Remaja Rosdakarya

Mondy, R.W., Sharplin, A. dan Flippo, E.B. (1988). Management, Concept and Practice. Boston: Allyn and Bacon, Inc

Muhadjir, Noeng. (1993). Metodologi Penelitian Kualitatif. Bandung: Remaja Rosdakarya 
Muliah, Siti (2017), Kompetensi Manajerial Kepala Madrasah (Studi Kasus di MTs Plus Karangwangi Subang. Tesis. Program Pascasarjana, UIN Sunan Kalijaga Yogyakarta,

Mulyasa, E (2007). Standar Kompetensi dan Sertifikasi Guru. Bandung: Remaja Rosda Karya

Nasution. (2003), Metodologi Penelitian Naturalistic Kualitatif, Bandung: Remaja Rosda.

Nawawi. H. (2003). Administrasi Pendidikan. Jakarta: PT Gunung Agung

Nurdin, Camelia leli, Dewi siti Aisyah,Debbik Nabilatul Faiziah (2015), Upaya Kepala Sekolah dalam meningkatkan Kinerja Guru di TKIT Al Irsyad Al Islamiyah Karawang. Jurnal Ilmiah Solusi Vol 2 No 5. Fakultas Agama Islam Universitas Singaperbangsa Karawang.

Pendidikan, Bandung: Penerbit PusTaka AlKasyaf.

Peraturan Menteri Pendidikan Nasional Republik Indonesia Nomor 13 Tahun 2007 Tentang Standar Kepala Sekolah dan Madrasah

Peraturan Menteri Pendidikan Nasional. (2007). Tentang Standar Kualifikasi Akademik dan Kompetensi Guru Peraturan Pemerintah Nomor 19 Tahun 2005 Tentang Standar Nasional Pendidikan

Purwanto, N. (1998). Administrasi dan Supervisi Pendidikan. Bandung: PT.Remaja Rosdakarya

Rahman (at all). (2006). Peran Strategis Kapala Sekolah dalam Meningkatkan Mutu Pendidikan. Jatinangor: Alqaprint.

Sa'ud, Udin Syaifudin. Dan Abin Syamsudin Makmun. (2011). Perencanaan Pendidikan Suatu Pendekatan Komprehensif. Bandung: PT. Remaja Rosda Karya

Sagala, S. (2002). Administrasi Pendidikan Kontemporer.Bandung: Alfabeta

Sahertian, Piet. A. (2000). Konsep Dasar dan Teknik Supervisi Pendidikan. Jakarta: PT. Rineka Cipta
Sanusi,A. (2017).Sistem Nilai. Bandung: Nuansa

Schuler, Randall S. (1987). Personal and Human Resource Management. Third

Siagian, S. P. (2004). Fungsi-Fungsi Manajerial. Jakarta: Penerbit Bumi Aksara

Silahahi, Ut. (2002). Studi tentang Ilmu Administrasi: Konsep, Teori, dan Dimensi. Bandung: Sinar Baru Algensindo.

Soetopo, H (1989) Konsep Dasar Administrasi Pendidikan.,. Malang: Penerbit IKIP Malang.

Sri Rahmi. (2003). Kepemimpinan kepala madrasah dalam meningkatkan profesionalisme guru (studi kasus di MAN 1 Malang). Tesis tidak diterbitkan. Malang: PPs UIN Malang

Stoner. James A.F. (1982). Management, Second Edition. Englewood Cliffs: Prantice Hal Inc

Sudjana, N (2012) Penilaian Hasil Belajar Mengajar, (Cet.XV). Bandung: PT Remaja Rosdakarya

Sudrajat, Akhmad. (tt). Kemampuan Manajerial Kepala Sekolah. http://andalascomunity.blogspot.com/2008/06/kemamp uan-manajerial-kepala-sekolah.html

Sugiyono. (2005). Memahami Penelitian Kualitatif. Bandung: Alfabeta.

Sutopo. (1999). Administrasi, Manajemen dan Organisasi. Jakarta: Lembaga Administrasi Negara

Syarifuddin. (2002). Manajemen Mutu Terpadu dalam Pendidikan: Konsep, Strategi dan Apliaksi. Jakarta, PT. Grasindo

Wijaya. David. "Manajemen Sumber Daya Manusia Pendidikan Berbasis Kompetensi Guru dalam Rangka Membangun Keunggulan Bersaing Sekolah". Jurnal Pendidikan Penabur Nomor 12 Tahun ke-8 Juni 2009

Yogaswara, Atep, Nanang Fattah, Udin Saefudin Sa'ud (2017),Kontribusi Manajerial kepala Sekolah dan Sistem Informasi Kepegawaian Terhadap Kenerja Mengajar Guru(Analisis Deskriptif Pada Sekolah Menengah Pertama Negeri di Kecamatan Perwakarta Kabupaten Purwakarta. Jurnal Penelitian Pendidikan Vol.II No 2 